\title{
Investigating the role of apiculture in watershed management and income improvement in Galessa protected area, Ethiopia
}

\author{
Tura Bareke Kifle, Kibebew Wakjira Hora, Admassu Addi Merti
}

Holeta Bee Research Centre, Oromia Agriculture Research Institute, Holeta, Ethiopia

\section{Email address:}

trbareke@gmail.com (T. B. Kifle)

\section{To cite this article:}

Tura Bareke Kifle, Kibebew Wakjira Hora, Admassu Addi Merti. Investigating the Role of Apiculture in Watershed Management and Income Improvement in Galessa Protected Area, Ethiopia. Agriculture, Forestry and Fisheries. Vol. 3, No. 5, 2014, pp. 380-385.

doi: $10.11648 /$ j.aff.20140305.18

\begin{abstract}
Beekeeping gives local people economic incentive for the preservation of natural habitats and is an ideal activity in watershed conservation program. The study was designed to assess and demonstrate the contribution of improved beekeeping for income generation and sustainable watershed management in Galessa protected area. For this purpose households were purposively selected based on their interest in beekeeping, experience in traditional beekeeping and proximity of residence to watershed areas. Training on beekeeping and integrations of beekeeping with watershed management were provided. Data of honey yield, bee plants, and annual income obtained from honey and field crops before and after improved beekeeping intervention were collected. Accordingly, the mean annual honey yield, income obtained from honey sales, bee forage planting practice and number of transitional hives owned by the beekeepers are significantly different between the sample households $(\mathrm{P}<0.05)$ before and after intermediate beekeeping intervention but the number of traditional hives owned was not significantly different between the household. The total honey yield has increased almost by two fold and the annual revenue increased by 6.5 folds. Therefore integration of intermediate beekeeping technology with conservation of watershed can enhance the income of household and encourages planting of bee forages which directly contributes for sustainable watershed managements. Thus demonstration and scaling up improved beekeeping technology should be promoted for sustainable watershed rehabilitation and to diversify the household income.
\end{abstract}

Keywords: Watershed, Rehabilitation, Beekeeping, Honey, Bee Forages

\section{Introduction}

Plants are primary producers in terrestrial ecosystems and direct providers of many ecosystem services such as carbon sequestration, prevention of soil erosion, nitrogen fixation, maintenance of water tables, greenhouse gas absorption, and food and habitat providers for most other terrestrial and many aquatic life forms (FAO, 2001). In Ethiopia, unwise extractions of the available forest resources for various purposes have resulted in the rapid depletion of natural forest resources. Because of that, there is a rapid decrease in the number of springs and pronounced decline in ground water table in highlands of Ethiopia (Kindu Mekonnen and Zenebe Admassu, 2008). The Holeta Agricultural Research Center identified 18 watershed constraints of which the losses of indigenous trees, the decline of spring discharge and land shortage due to high population pressure. These problems were also confirmed by most farmers at Galessa watershed to be the top priority problems. This calls for coordinated effort by policy makers, development experts and researchers to look for alternative development options to enhance forest conservation and which in turn improves watershed system in general.

Beekeeping is an incentive for planting trees and protecting existing trees, because trees are very important for bees and therefore for beekeepers as well (Crane 1999; FAO, 2003). On top of this honeybees serve as pollinating agents for numerous species of plants and contribute to their survival, genetic prosperity and play a crucial role in the maintenance of ecosystem services (FAO, 2004). In past few years, few attempts have been made by Farm Africa to implement beekeeping technologies around Chillimo state forest as incentive for conservation of existing natural forest by providing beekeeping accessories and training to farmers 
living in or close to the forests to practice beekeeping for honey production (Regassa Ensermu et al., 1998.). However, due to lack of proper follow-up, research intervention and also the pilot project did not encompass all farmers in and around the forest area; the attempts did not hit the desired target. Therefore, in this research activity an attempt was made to assess the role of beekeeping in watershed conservation around the Galessa watershed area with active involvement of the community to improve their livelihood and to enhance the watershed rehabilitation.

\section{Methodology}

\subsection{Study Site}

The study was undertaken at Galessa watershed which is delineated by Holeta Agriculture Research Centre and located in Dendi Woreda, West Shewa Zone of Oromia Regional State of Ethiopia. The altitude of watershed area ranges from 2900-3200 m.a.s.l with bimodal rainfall patterns (Mekonnen, 2007 ) and located in grid points of $09^{\circ} 06^{\prime} 54^{\prime \prime} N$ to $09^{\circ} 07^{\prime} 52^{\prime \prime} \mathrm{N}$ and $37^{\circ} 07^{\prime} 16^{\prime \prime} \mathrm{E}$ to $37^{\circ} 08^{\prime} 54^{\prime \prime} \mathrm{E}$.

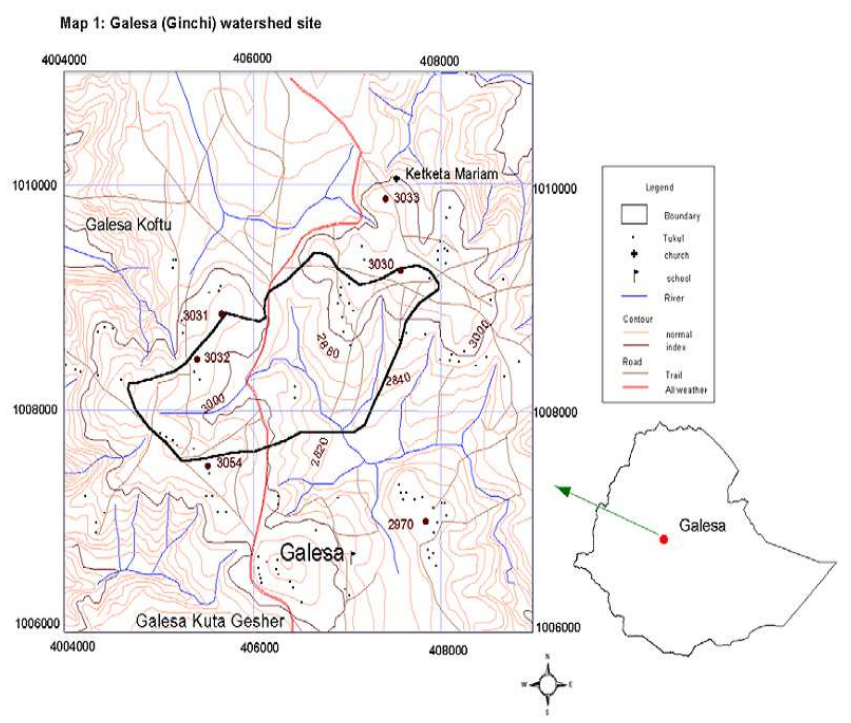

Figure 1. Map of Galessa Watershed

\subsection{Methods}

\subsubsection{Household Selection and Farmer Research Group (FRG) Establishments}

Proximity to watershed areas is a factor that was accounted when selecting the demonstration site. Galessa Koftu kebele which is close to the watershed was selected for demonstration of the technology. People who practice beekeeping were purposively selected based on their interest in beekeeping, experience in traditional beekeeping and proximity of residence to watershed areas and 2 FRG groups consisting a total of 20 households were selected to conduct the demonstration of beekeeping technology. Only 105 traditional hives were found in the watershed. Of these 60 were included in our demonstration and transferred to transitional hives. After the establishment of FRG initial sensitization workshop was held and memorandum of agreement was signed by the member of the FRG, Holeta Bee Research Center Researchers and Ministry of Agriculture and Rural Development. Practical training on honeybee transferring from traditional to improved hives, seasonal colony manipulation and intermediate beehive construction were carried out. The participants were also introduced about the integration of beekeeping with watershed management. Before starting, watershed preliminary assessment was done to get present information concerning the households living in the delineated watershed areas. Socioeconomic data was collected from FRG members using semi structured questionnaire before and after improved beekeeping technology involvement. All the necessary beekeeping management practices such as inspection, feeding, supering, super reducing etc were undertaken. Honey yield and income were obtained and compared to income obtained from sale of major crops (barley, wheat and potatoes) grown in the area. On top of this the attitude of farmers towards watershed rehabilitation was recorded. A number of plant species conserved and planted was recorded around home garden

\subsubsection{Data Management and Statistical Analysis}

Data of honey yield, income obtained from honey, the watershed management practice in relation to beekeeping, the contribution of beekeeping in the livelihoods of the households, the attitude of the farmers toward planting bee forage planting and constraints of beekeeping were collected. The data analysis was undertaken using index (Falconer and Mackay, 1996), descriptive statistics and t-test by Statistical Package for the Social Sciences (Spss) software.

\section{Result and Discussion}

According to the beekeepers socioeconomic assessment, the mean annual honey yield, income obtained from honey sales, bee forage planting practice and number of transitional hives owned by the beekeepers are significantly different between the sampled households $(\mathrm{P}<0.05)$ before and after beekeeping intervention but the number of traditional hives owned was not significantly different between the household (Table1).

Table 1. Mean \pm Standard error of honey yield, number of hives owned and bee forage planted before and after beekeeping intervention

\begin{tabular}{llll}
\hline Intervention & Annual average honey yield in kg & $\begin{array}{l}\text { Mean number of traditional } \\
\text { hives owned }\end{array}$ & $\begin{array}{l}\text { Mean number of transitional } \\
\text { hives }\end{array}$ \\
\hline Before beekeeping & $7 \pm 0.94 \mathrm{a}$ & $1.7 \pm 0.193 \mathrm{a}$ & $0 \pm 0 \mathrm{a}$ \\
After beekeeping & $22 \pm 2.3 \mathrm{~b}$ & $0.85 \pm 0.29 \mathrm{a}$ & $2 \pm 0.25 \mathrm{~b}$ \\
& Different letters show significance difference & $70 \pm 10.4 \mathrm{~b}$ \\
\hline
\end{tabular}



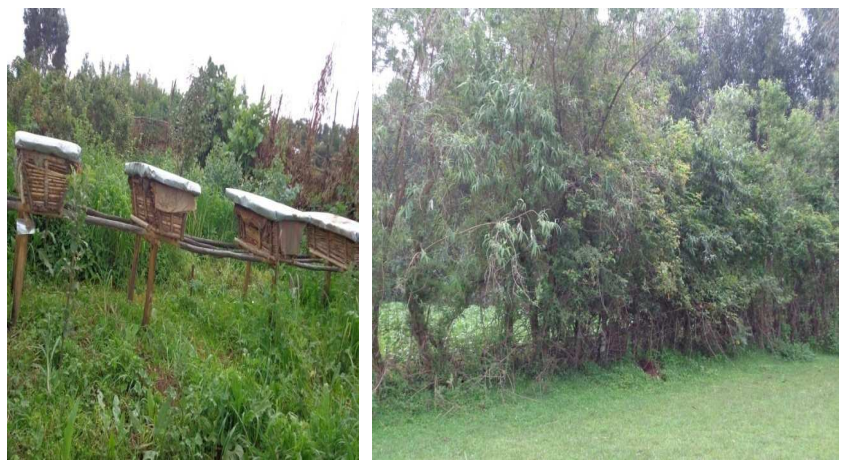

Figure 2. Home garden beekeeping apiary of the sample household

\subsection{Honey Yield}

Amount of honey harvested was $7 \mathrm{~kg}$ in traditional hives before project intervention and increased to $22 \mathrm{kgs}$ per hive after changed to intermediate hives. The total honey yield has increased almost by two fold and the annual revenue increased by 6.5 folds after beekeeping projects. This indicated that improved beekeeping practices contributes to income generation of the households and reduce deforestation of the trees in the watershed. This was supported by Hussein`s (2000) findings which confirm that beekeeping enhances the income generation potential of small holders and promotes the conservation and utilization of natural resources that are being rapidly depleting. Beekeeping is a practical tool for raising an awareness of the communities to manage watersheds and could favor watershed conservation (Alemtsehay, 2011; Albersand and Robinson, 2011). The products of the beehives (honey, beeswax, pollen and Propolis) are a rich source of nutrients and can be of world quality, and for which there are significant local and international markets (Lietaer, 2009). These activities are not only generating income from sale of honey for watershed user group but also able to sustain the resources through tree plantation, access to improved beekeeping technologies and expensive bee equipment.

Farmers did not increase the number of traditional hives after improved beekeeping technology demonstration because of its low yield and unsuitability to manage honeybee colonies (GRM International, 2007).

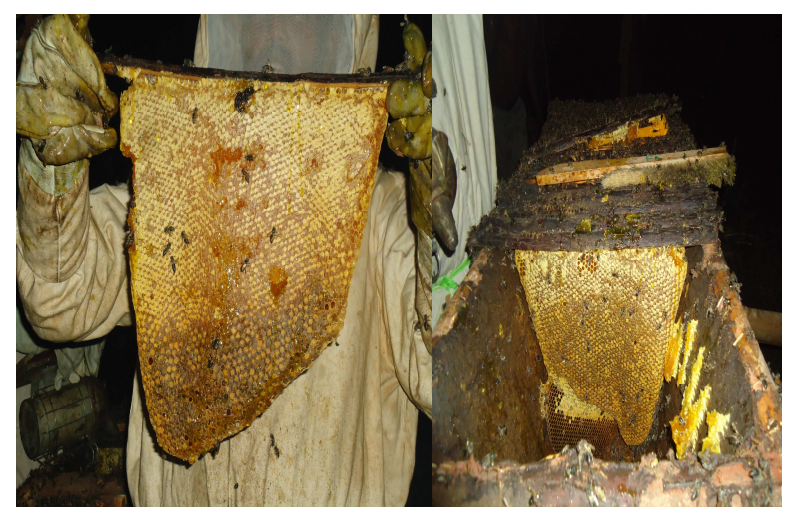

Figure 3. Honey harvested from intermediate hives in the watersheds

\subsection{Contribution of Beekeeping to Household Income Compared with Major Crops Grown}

The results indicated that potatoes contribute $68.7 \%$, barley 17.5 , wheat $9.6 \%$ to households' incomes while honey contributes only $4.2 \%$. Even though the income obtained from beekeeping was low compared to those from major crops, (Figure 4).

\section{proportion(\%)}

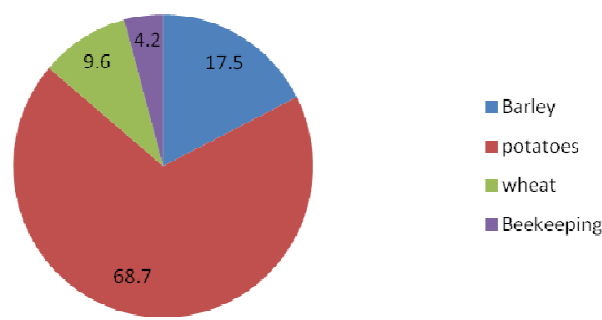

Figure 4. Proportional contributions of beekeeping and major crops to household income

\subsection{Bee Forage Planting}

The mean number of bee forage planted annually by the beekeepers before beekeeping intervention was 42 plants per sampled farmers and 124 plants per beekeepers after beekeeping intervention. The bee forage development has increased by 2 folds (Table 1). Attitude of beekeepers towards watershed integrated beekeeping technology is a very important phenomenon to take into consideration for multipurpose bee forages planting. Many countries introduced improved beekeeping as reforestation incentives, paying special attention to plant flowering trees that provide nectar and pollen whilst generating income for local communities from bee products (FAO, 2003; Steffan and Kuhn, 2003; Decourtye, et al, 2010). Diversification of cropping systems team such as vegetables, legumes, oilseeds, and forage crops in watershed improved the rainwater harvesting capacity and the impacts on environmental resources (Adugna, 2002).Crop varieties planted in watershed observed as major honeybee forage and important to maximize honey yield and spread the farmer's economic risk. Moreover, the crop growers benefited from the pollination services of the honeybees indirectly but not yet quantified. A mixture of different weedy species maintained between crop boarders and uncultivated land of watershed contributed as major honeybee forage, rain water harvesting, watershed biodiversity conservation and climate adaption as well (Tolera Kumsa, 2014).

The plant species planted by the beekeepers before beekeeping intervention were mainly planted for fuel wood requirement, cash income and watershed conservation. Some of them are not visited by honeybees. (Table 2) 
Table 2. List of plant species before the project

\begin{tabular}{lll}
\hline Plant species & family & growth habit \\
\hline Juniperus procera & cupressaceae & tree \\
Arundinaria alpine & poaceae & shrub \\
Eucalyptus globulus & Mrytaceae & tree \\
Acacia decurrens & Fabaceae & tree \\
Dombeya torrida & Sterculiaceae & tree \\
Chamecytisus proliferus & Fabaceae & shrub \\
Buddleja polystachya & Buddlejaceae & shrub \\
Hagenia abysinica & Rosaceae & tree \\
\hline
\end{tabular}

Table 3. List of bee forage plant species newly adopted after the project

\begin{tabular}{lll}
\hline Plant species & family & growth habit \\
\hline Callistemon citrinus & Mrytaceae & shrub \\
Albizia gummifera & Fabaceae & tree \\
Dovyalis caffra & Flacourtiaceae & shrub \\
Olea africana & Oleaceae & tree \\
Prunus africana & Oleaceae & tree \\
\hline
\end{tabular}

The number of bee forage trees planted varied from household to household. Most of households planted Eucalyptus globulus more than the other species. Because the timber of Eucalyptus globulus also provide income through selling for different construction.

\subsection{Types of Plant Species Preferred for Watershed Management}

Researchers together with farmers identified more than 16 trees, shrubs and herbaceous plant species around homesteads, farm land and other niches (Table 4). Of these $88.2 \%$ were bee forage plants. Therefore, integration of improved beekeeping technology with watershed management is very crucial to diversify the annual income of the household. It is an alternative income generating activities which can be an appropriate solution for sustainable watershed development and encourage the farmers toward tree planting. Past conservation efforts in Ethiopia have only concentrated in developing watershed conservation programs without addressing the socioeconomic of watershed communities. Community ownership and participation in conservative initiatives is critical to sustainable conservation of watersheds (Lietaer, 2009). Therefore, integrating improved beekeeping technologies and natural resources development offers a pathway that guarantees sustainable watershed management. It is common knowledge that beekeeping is dependent on natural resources and therefore any effort to improve beekeeping in watershed areas, should be hand in hand with the natural resources development (Tolera Kumsa, 2014). Legesse Negash in (2002) stated that nowadays it has become clear that the land degradation issue could be solved through a holistic approach that addresses land reclaiming, sustainable utilization and diversifying livelihood options so as to reduce the pressure on the biodiversity through beekeeping technology.
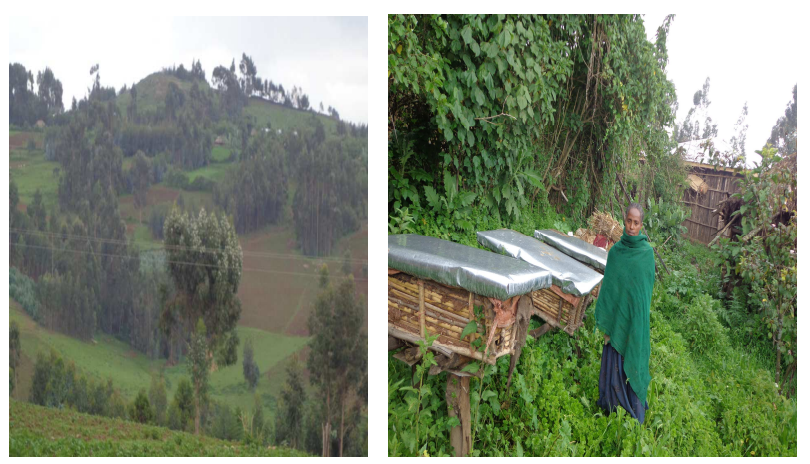

Figure 5. Galessa Watershed and beekeeping practice

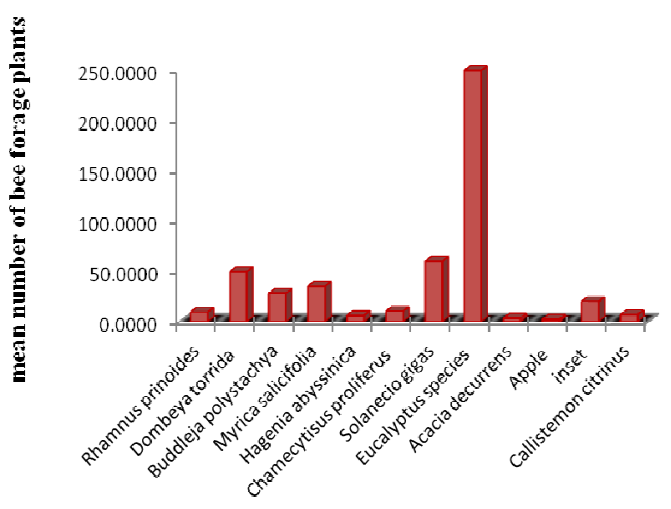

$$
\text { Bee plant species }
$$

Figure 6. Bee tree planting status of beekeepers around apiary (Home garden)

Table 4. Types of plant species preferred for Galessa watershed management

\begin{tabular}{llllll}
\hline No & plant species & Family & local name & Habit & other uses \\
\hline 1 & Acacia decurrens & Fabaceae & Kacha & tree & fuel wood \\
2 & Arundinaria alpine & Poaceae & Bamboo & shrub & construction \\
3 & Buddleja polystachya & Buddlejaceae & Anfara & shrub & fuel wood \\
4 & Chamaecytisus proliferus & Fabaceae & Treelucern & shrub & animal feed and fuel wood \\
5 & Dombeya torrida & Sterculiaceae & Dannisa & tree & fuel wood and fences \\
6 & Eucalyptus globulus & Mrytaceae & Barzaf & tree & construction, fuel wood and \\
7 & Hagenia abysinica & Rosaceae & Heto/Koso & tree & timber, medicine and \\
8 & Juniperus procera & Pupressaceae & Gatira & tree & timber, fence and house construction \\
9 & Kalanchoe deficiens & Crassulaceae & Bosoke & herb & fuel wood \\
10 & Maesa lanceolata & Myrsinaceae & Abayyi & shrub & fence and fuel wood \\
11 & Myrica salicifolia & Sapindaceae & chongi & shrub & fence and fuel wood \\
\hline
\end{tabular}




\begin{tabular}{llllll}
\hline No & plant species & Family & local name & Habit & other uses \\
\hline 12 & Phytolacca dodecandra & Phytolaccaceae & Andode & herb & cloth washing and traditional medicine \\
13 & Solanecio gigas & Asteraceae & Osole & shrub & fences \\
14 & Urtica simensis & Uritaceae & Dobi & herb & food \\
15 & Vernonia amygdalina & Asteraceae & Ebicha/Girawa & shrub & animal feed, medicine and to scour pots used for \\
16 & Vernonia auriculifera & Asteraceae & Reji & shrub & fence, fuel wood and animal feed \\
\hline
\end{tabular}

\subsection{Beekeeping Constraints of Galessa Watershed}

Based on the response of the respondents among the seven constraints, herbicide use was the first serious problem for the decline of bee colonies. One of the mismanagement practicing is that farmers extensively using various types of pesticides near apiary sites without considering the damages caused on bee colonies, so that a number of bee colonies either die or abscond. The study conducted by Arse G. et al, (2010) also revealed that shortage of honeybee colonies due to poisoning from agro-chemical is the current obstacle to beekeeping.

Table 3. Ranked beekeeping constraints of Galessa Watershed

\begin{tabular}{|c|c|c|c|c|c|c|c|}
\hline Major beekeeping constraint of the area & $1^{\text {st }}$ rank & 2cd rank & $3^{\text {rd }}$ rank & $4^{\text {th }}$ rank & $5^{\text {th }}$ rank & $6^{\text {th }}$ rank & Index \\
\hline Lack of bee forage & 14.3 & 21.3 & 17.9 & 0 & 0 & 14.3 & 0.31 \\
\hline Decline of bee colony & 0 & 10.7 & 10.7 & 39.3 & 0 & 0 & 0.24 \\
\hline Herbicides and pesticides problem & 46.4 & 42.9 & 21.4 & 3.6 & 0 & 3.6 & 0.65 \\
\hline Pests and predators & 0 & 14.3 & 25 & 3.6 & 3.6 & 0 & 0.21 \\
\hline lack of bee colony & 28.6 & 3.6 & 14.3 & 21.4 & 75 & 46.4 & 0.56 \\
\hline Cost of beekeeping equipment & 10.7 & 7.1 & 10.7 & 21.4 & 21.4 & 21.4 & 0.3 \\
\hline
\end{tabular}

Index $=$ sum of $[6$ for rank $1+5$ for rank $2+4$ for rank $3+3$ for rank $4+2$ for rank $5+1$ for rank 6 ] for particular beekeeping constraints divided by sum of [ 6 for rank $1+5$ for rank $2+4$ for rank $3+3$ for rank $4+2$ for rank $5+1$ for rank 6 ] for all beekeeping constraints of the area

\subsection{Attitude toward Improved Beekeeping}

Attitude of the beekeepers towards watershed integrated beekeeping technology is a very important phenomenon to take into consideration for sustainable adoption of improved beekeeping in watershed conservation. They have developed awareness on the value of beekeeping for conservation and income generation as the result they have brought relatively better attitudinal change towards improved beekeeping technology and planting of different bee forage plants after this demonstration. It indicated that the majority of the watershed respondents (95\%) had positive attitude towards watershed integrated beekeeping and honey production. However, $5 \%$ of the respondents had neutral attitude and none of the respondents had negative attitude towards the technology in the study area. This showed how much the beekeeper farmers are understood the economical and ecological importance of beekeeping.

\section{Conclusion and Recommendations}

As a result of this demonstration, the average annual income of the beekeeper household from honey sale has increased, indicating that the integration of beekeeping with conservation and rehabilitation of natural resources would be an important incentive to mobilize communities to participate in rehabilitation programs for both economic and environmental reasons. The bee forage growing practice of the beekeepers have increased and thus beekeepers have due regard for watershed management and planting bee forages for bees.
Based on this study, Galessa watershed is a suitable area to initiate bee farming. However, attention must be given to maintain the existing bee flora and multiplication of multipurpose bee plant species in order to make it sustainable. Cost of beekeeping equipment and lack of bee colony is also the other main bottle neck problem to expand beekeeping technology and therefore queen rearing technology is recommended. As well as the demonstration and scaling up this technology should be promoted for sustainable watershed rehabilitation and to diversify the household income

\section{Acknowledgements}

I am thankful to Holeta Bee research Center and Oromia Agricultural Research Institute for providing required facilities and logistics. My sincere thanks also extended to Konjit Asfaw and Tesfaye Abera, for their inspiration and support in the implementation and follow-up of the research. I am thankful to all the watershed user groups and partners for their contribution towards this successful of the project.

\section{References}

[1] Adugna, W. 2002. Genetic diversity analysis of linseed under different environments. PhD thesis, Department of Plant Breeding, Faculty of Agric. Univ. of the Free State, Bloemfontein, South Africa.

[2] Albers, H.J. and Robinson, E.J. 2011. The trees and the bees: using enforcement and income projects to protect forests and rural livelihoods through spatial joint production. Agricultural and resource economics review 40/3: 424-438. 
[3] Alemtsehay, T. 2011. Seasonal availability of common bee flora in relation to land use and colony performance in Gergera watershed Atsbi Wembwrta District Eastern Zone of Tigray, M.Sc Thesis, Wondo Genet College of Forestry, School Of Graduate Studies, Hawassa University, Hawassa, Ethiopia

[4] Arse Gebeyehu, Tesfaye Kebede, Sebsibe Zuber, Tekalign Gutu, Gurmessa Umeta, Tesfaye Lemma and Feyisa Hundessa, 2010. Participatory rural appraisal investigation on beekeeping in Arsi Negelle and Shashemene districts of West Arsi zone of Oromia, Ethiopia

[5] Debissa, L. 2006. The Roles of Apiculture in Vegetation Characterization and Household Livelihoods in Walmara District, Central Ethiopia. M.sc. Thesis, Wondo Genet College of Forestry, School Of Graduate Studies, Hawassa University, Hawassa, Ethiopia

[6] Decourtye, A; Mader, E. \& Desneux, N. 2010. Landscape enhancement of floral resources for honey bees in agroecosystems.Apidologie, Vol.41, pp. 264-277.

[7] Falconer D.S and Mackay T.F.C.1996 Introduction to Quantitative Genetics. $4^{\text {th }}$ ed. Longman Group Ltd., Malaysia, $464 \mathrm{pp}$.

[8] FAO (2001). Global Forest Resources Assessment 2000-main report. FAO Forestry Paper No. 140, Rome.

[9] FAO, 2003. State of the World's Forests. Food and Agriculture Organization of the United Nations, Rome.

[10] FAO, (2004). Conservation and management of pollinators for sustainable agriculture-The International response. A contribution to the International Workshop on solitary bees and their role in pollination held in Berberibe, Cerara, Brazil, PP 19-25.

[11] GRM International (2007) .Livestock Development master plan study phase I report-Data collection analysis Volume Apiculture
[12] Hussein, M. 2000. Beekeeping in Africa. In: Apiacta 1/2000: $32-48$.

[13] Legesse Negash. (2002). Review of research advances in some selected African trees with special reference to Ethiopia. [Review article]. Ethiop. J. Biol. Sci. 1: 81-126.

[14] Lietaer, C. 2009. Impact of beekeeping on forest conservation, preservation of forest ecosystems and poverty reduction. XIII World Forestry Congress, $18-23$, Argentina.

[15] Mekonnen, K. (2007), "Evaluation of selected indigenous and exotic tree and shrub species for soil fertility improvement and fodder production in the highland areas of western Shewa, Ethiopia", doctoral thesis, Department for Forest and Soil Sciences, University of Natural Resources and Applied Life Sciences, Vienna.

[16] Paterson, P.D. (1999), Constraints in transforming traditional to modern beekeeping in Kenya. In the conservation and utilization of commercial insects, Proceedings of the first international workshop, (Raina, S.K, Kioko, E.N. and Mwanycky, eds.). Nairobi, 18-21 August, 1997. pp 95-102.

[17] Regassa Ensermu, W.Mwangi, Hugo Verkuijle and Mohammed Hussen. 1998. Farmers' Seed Sources and Seed Management in ChilaloAwuraja, Ethiopia. Mexico, D. F: IAR/CIMMYT

[18] Steffan-Dewenter, I. and Kuhn, A. 2003. Honeybee foraging in differentially structured landscapes. Proceedings of the Royal Society of London Series B-Biological Sciences, Vol.270 pp. 569-575.

[19] Tolera Kumsa Gemeda. Integrating Improved Beekeeping as Economic Incentive to Community Watershed Management: The Case of Sasiga and Sagure Districts in Oromia Region, Ethiopia. Agriculture, Forestry and Fisheries. Vol. 3, No. 1, 2014, pp. 52-57.doi: 10.11648/j.aff.20140301.19 